\title{
Social Movements Seen as Radical Political Actors: The Case of the Polish Tenants' Movement
}

\author{
Katarzyna Jezierska ${ }^{1}$ (1) $\cdot$ Dominika V. Polanska ${ }^{2}$
}

Published online: 27 November 2017

(C) The Author(s) 2018

\begin{abstract}
This article casts new light on the processes of collective claims and identity formation in social movements, with the help of the radical political framework of Laclau and Mouffe (Hegemony and socialist strategy: towards a radical democratic politics, Verso, London, 2001). Polish tenants, classified as "losers" of transition and marginalized in the mainstream discourse, nevertheless act collectively, mobilizing alliances with other democratic struggles and thus challenge the hegemony of neoliberal dogmas in the country. The very fact of mobilization of a socially and economically deprived group demanding the right to the city is provocative in the studied context. The empirical foundations of our study are 20 in-depth semistructured interviews conducted with Polish tenants' activists cross-referenced with media material produced by and about the movement, and previous studies on the topic. The contribution of this article is twofold: it combines social movement theory with radical political framework and fills the empirical gap in the body of literature on social movements in post-socialist Europe.
\end{abstract}

Original article submitted for Voluntas special issue "The City and Social Mobilization: Rights, Actors and Fields in times of Urban Crisis”, editors: Anna Domaradzka and David Dueñas i Cid.

Update 22 August 2018 The PDF version of this article was reformatted to a larger trim size.

Katarzyna Jezierska

katarzyna.jezierska@gu.se

1 Department of Political Science, Centre for European Research (CERGU), University of Gothenburg, Sprängkullsgatan 19, 40530 Gothenburg, Sweden

2 Institute for Housing and Urban Research, Uppsala University, Uppsala, Sweden
Keywords Radical politics - Social movements · Civil society $\cdot$ Tenants' movement $\cdot$ Collective identity $\cdot$ Poland

\section{Introduction}

Social movements, defined as "a process whereby several different actors $[\ldots]$ come to elaborate $[\ldots]$ a shared definition of themselves as being part of the same side in a social conflict" (Diani 1992, p. 2), are often perceived by scholars as potential actors of social change. Historically, social movements have demonstrated the capability of bringing about change in the perception of certain social issues. Through their actions, issues previously seen as "unthinkable" have become center stage in political debates, shifting the way we think of equality, environment, or civil rights for instance. Koopmans (1993) argued that what is perceived as radical in a society often depends on the state and its responses. For example, during the 1960s the environmental movement was characterized as radical before its claims got "translated into political action by governments" and international conventions in the 1970s, and later by the formation of new green political parties worldwide (McCormick 1989, p. xi). Importantly, in order to become a challenge to the status quo, even radical social movements need to articulate their collective claims and identity within the frames of the existing order (Polletta and Jasper 2001; Tarrow 1998).

This article focuses on the articulation of a collective identity of an urban social movement that is considered radical due to its claims and repertoires of action, in a geographical context that hitherto has been rather neglected in social movement studies in post-socialist Europe. We are interested in analyzing how the Polish tenants' movement is articulating its collective claims and identity, thus 
challenging dominant neoliberal ${ }^{1}$ ideas in Polish society. The context in which the movement operates is important here, and we argue that neoliberal orientation in politics and economy has won a hegemonic position in Poland resulting in a division between the "winners" and "losers" of transition, classifying tenants as remnants of the past, state-socialist system. In light of this context, the research questions guiding this work are:

- How does the tenants' movement articulate its claims in the existing context?

- How do tenants negotiate their collective identity between equality and difference?

- How can these processes be conceptualized with the tools of a radical political framework?

The contribution of this article is twofold. Firstly, we aim at combining social movement theory with a radical political framework in order to understand the case of the Polish tenants' movement, hopefully contributing to the theories on radical movements and their claim-making. Secondly, the ambition is of a more empirical characterto fill in the gap in the body of literature on social movements in the post-socialist part of Europe.

In this article we apply a theory of radical politics on the movement we study. We borrow the tools developed to make sense of how counter-hegemonic politics are produced, what enables and what constrains its emergence. The most prominent contemporary theory of radical politics is found in the writings of Laclau and Mouffe ([1985]2001), Laclau (2005), Mouffe (1993, 2005, 2013). Their work is mainly of theoretical-normative character, but it is by no means bereft of empirical references. Hence, its application to analyses of actual social movements is motivated. As Robinson and Tormey (2009, p. 140) argue, "Laclau himself-in his work on populism (Laclau 2005) — and Laclau and Mouffe's followers, such as Norval and Stavrakakis, apply their views in specifically empirical contexts." Even though Laclau and Mouffe never became a dominant framework for studying social movements, references to their work can be found in studies of social movements (see, e.g., Escobar 1992, p. 38-40; Howarth et al. 2000; Poletta and Jasper 2001, pp. 285, 286; Robinson and Tormey 2009). Norval claims that we need to further explore how concrete hegemonic formations condition the emergence of certain collective identities: "Further research into the formalization of the relations between the division of political space and the presence or

\footnotetext{
${ }^{1}$ In line with Wendy Brown (2015) we define neoliberalism as a governing rationality interpreting and evaluating different spheres of our reality as markets, in this way justifying extreme inequalities in wealth and living conditions.
}

absence of specific modalities of subject formation is needed" (2000, p. 227).

By applying the radical political framework, we want to analyze processes of change and identity formation in a social movement. The empirical foundations of our study are 20 in-depth semi-structured interviews conducted with tenants' activists in 2013. Interviews were conducted with activists of the three biggest and most active tenants' organizations in the Polish capital (Warsaw Tenants' Association, Committee for the Defense of Tenants' Rights, and Social Justice Office) along with tenants' activists in smaller tenants' associations or more "loosely associated" tenants' activists. The leaders of most active tenants' associations were chosen as interviewees, among other tenants' activists in order to include as varied experiences and perspectives as possible. Seven women and thirteen men took part in the interviews, and the average age of the interviewees was 45.2 years, with the youngest interviewee being 27 years old and the oldest 65 . The length of their engagement in tenants' issues (including formal and informal activism related to tenants' issues) varied from 2 to 20 years. $^{2}$ The interview material was then transcribed, coded thematically, and analyzed. The coding was systematical and reduced data into codes that were later clustered into overarching themes. Some of the themes found in the material reflected the questions posed to the respondents; however, also other themes appeared. The analysis focused on themes concerning identity perceptions, claim formation, and collaboration with other civil society actors. Interview material was cross-referenced with media material produced about and by the tenants' movement. All interviewees were anonymized, and our main focus is on the articulation process of claims and collective identity of tenants. ${ }^{3}$

The article begins with an introduction to the theoretical framework guiding this study followed by a presentation of the empirical case we examined. We briefly describe the research field on social movements and civil society in post-socialist Europe and focus on Poland and the Polish tenants' movement. Next we present our analysis, concentrating on the articulation processes within the tenants' movement and their alliances with various other actors such as squatters and trade unions. Finally, we conclude that the specific Central European context has shaped the range of possible claims and available repertoire of actions of the studied movement that in the face of the neoliberal

\footnotetext{
2 The respondents were mainly involved in tenants' issues, while a few of them were also active members of political organizations and trade unions.

3 As the included interviews were conducted by one of the authors, the analysis of the material was divided between the authors in order to not go against the confidentiality and established agreements made with the interviewees.
} 
hegemony adjusted its claims, targeting both the abstract capitalist mode of economy and the concrete municipal strategies applying the neoliberal logic.

\section{Radical Politics as a Theoretical Framework}

The post-structuralist version of radical politics explains political processes through the concept of hegemony. Following Antonio Gramsci, it distinguishes between hegemony and domination, where hegemony stands for persuasion, the cognitive and emotional appeal, while domination is equated with rule by force (Gramsci 1971, pp. 57-59). Hegemony is established through a chain of equivalences between various demands, so as to transform them into claims challenging the existing structure of power relationships. The democratic demands present in a given society do not necessarily converge, and they can even be in conflict with each other, which is why they need to be articulated politically. "Elements whose own nature does not predetermine them to enter into one type of arrangement rather than another, nevertheless coalesce as a result of an external or articulatory practice" (Laclau and Mouffe 2001, p. xii). A chain of equivalence is created by broadening or abstracting local claims (both spatially and in the sense of transcending the idiosyncratic appeal) into more general, or universal ones to make them attractive to other groups, forming a basis for questioning dominant ideas.

Articulation, i.e., linking of elements not necessarily linked (constructing a chain of equivalence), leads to a division of the social space into antagonistic oppositions. Drawing of (symbolic) frontiers is identified as the fundamental mechanism delimiting identities and discursive formations, and thus the basic mechanism defining politics-politics cannot exist without frontiers. "It is through the consolidation or dissolution of political frontiers that discursive formations in general, and social and political identities more specifically, are constructed or fragmented" (Norval 2000, p. 220). Forming a chain of equivalence and designation of frontiers is linked to the moment of negativity (Laclau and Mouffe 2001, p. 143-144), i.e., it involves naming the Other - the nodal points of power that need to be targeted and transformed to create the conditions for a new hegemony (Mouffe 2008). In other words, a social formation, e.g., a social movement, is established through aligning different groupings that recognize a shared antagonist and unite against it (Jezierska 2011). What is at stake is a creation of a common identity, a "we," which requires the determination of a "they." Obviously, the Other is not limited to concrete, physical others, but represents the oppressive forces that could be abstract processes the group opposes. In some cases, articulation can be indirect, i.e., through naming only the Other and leaving the content of the One open to be filled. The drawing of frontiers, which establishes antagonisms, is never definite or full since "[a]ntagonism only exists as a discursive effect and only as one end of a spectrum that is never reached. If anything, there are tendential antagonisms, that is, frontiers and identities that are constituted as more or less antagonistic" (Thomassen 2005, p. 296). Thus, both antagonism (the division of the discursive space) and the consolidation of a chain of equivalence are imperfect and merely temporary constructs. The antagonistic, equivalent logic is balanced by the logic of difference. The unity created by the relationship of equivalence does not erase differences between the united elements. The differences are only temporarily suspended, and both logics_of equivalence and difference — are dynamically at work (Mouffe 1993).

Importantly, " $[\mathrm{t}]$ he articulation of different demands according to democratic equivalences means not merely establishing alliances but actually modifying the very identity of these forces" (Handler 1992, p. 702). Thus articulation is "any practice establishing a relationship among elements such that their identity is modified as a result of the articulatory practice" (Laclau and Mouffe 2001, p. 105). This means that radical politics involves a renegotiation and potential destabilization of identity. When demands are articulated in a new fashion, aligned with other demands, identities will adjust.

In short, the process of forming a counter-hegemonic movement can be described as follows:

Social actors occupy differential positions within the discourses that constitute the social fabric. In that sense they are all, strictly speaking, particularities. On the other hand, there are social antagonisms creating internal frontiers within society. Vis-à-vis oppressive forces, for instance, a set of particularities establish relations of equivalence between themselves. It becomes necessary, however, to represent the totality of the chain, beyond the mere differential particularisms of the equivalential links. (Laclau and Mouffe 2001, p. xiii)

The movement needs to define the Other that it opposes, and also needs to search for some signifiers that will unite the particularities.

To some extent, previous literature on social movements already covers the aspects of collective struggles underlined by the radical political framework presented above. We gather the scattered contributions in the ample social movement literature in one comprehensive framework of the dynamics between internal forces within the movement, its collaboration with other movements, and interactions with the surrounding system. To our knowledge, this is the 
first attempt to systematically apply the radical political framework to the field of social movements. In existing studies of social movements, scholars focus on political opportunity structures to highlight the contextual conditions that enable and hamper possibilities of social mobilizations (for an overview see Kriesi 2004). Even though originally not included, in more recent studies even discursive opportunities and constraints have gained attention (e.g., Koopmans and Statham 1999). In the radical political framework applied here, the discursive opportunity structures, mirrored in political and economic opportunities, correspond to the notion of hegemony. Various aspects of collective identity formation and internal dynamics of movement consolidation or disintegration have also been addressed by social movement scholars (e.g., Melucci 1995; Della Porta and Diani 1999). Here the radical political contribution stresses the fragility of any identity construction, as a result of continuous balancing between logics of equivalence and difference. It also highlights the processes of becoming a subject, or subjectification, of social movements. Collective action constitutes engaged actors as subjects who have a voice and who are listened to (Prentoulis and Thomassen 2013). Some social movement scholars have also stressed the role of negativity in processes of identity formation, that is, identification of a common Other (see, e.g., Melucci 1995, 1996; Della Porta and Diani 1999). The radical political framework further highlights the necessary element of antagonism and, yet again, its partial character. Since the contours of social space are never set, any Other (abstract or concrete) will only temporarily be defined. In sum, the specific contribution of the radical political framework is the realization of the fragmented nature of any identity formation. While attempts at creating a chain of equivalence reduce the complexity of the social space, the differences are only temporarily suspended. It also helps conceptualize the necessary negativity of any identity construction, together with the realization of the fragility of any concrete antagonistic relationship. It further highlights the transformative aspects of collective action by focusing on how identities shift though social action in the process of subjectification, or becoming subjects. Finally, this framework hints at the possibility of disruption of current hegemony through the establishment of a chain of equivalence between different democratic demands in a counter-hegemonic position. In this sense, it aligns well with the "Right to the City" idea which links demands ranging from advocacy to service provision, political representation as well as down-to-earth problem solving.

For the purposes of our study of the tenants' movement in Poland, the radical political framework provides several conceptual tools. First, the concept of hegemony is useful to understand the ruling discursive opportunity structure of the Polish civil society, providing a backdrop for the analysis. Second, we employ the idea of two competing logics creating the dynamics of social movements (logics of equivalence and difference) and the idea of the Other as the constitutive, unifying factor in shaping the identity of a movement. The concept of (re)articulation of demands and subjectification will serve to understand the processes of creating a chain of equivalence, common identity and molding change.

\section{Radical Politics, Civil Society and Social Movements}

Radical democrats often put their hopes for political renewal in civil society. ${ }^{4} \mathrm{~A}$ radical democratic perspective on civil society emphasizes its political, conflictual aspects, e.g., the capability of civil society to politicize new issues and to disrupt the division between the private and the public. Laclau and Mouffe argued that "hegemonic articulations start at the level of civil society" (Laclau and Mouffe 2001, p. xii). As one commentator observes, it is not a naïve belief in the unconstrained forces of civic activism, because these are pictured as circumvented by the prevailing net of power structures: "Of course, few radical democrats think that presently constituted civil societies can, in and of themselves, bring about the kind of pluralism and participation that is suggested here. Too often, civil relations are dominated by institutional orders that limit and disperse whatever critical power exists within them" (Martin 2009, p. 94). Nevertheless, the hope put in the critical potential of civil society, inherited from Antonio Gramsci, is acknowledged, and it is here that counterhegemonic formulations are sought. Civic activism is viewed as efforts to redefine the boundaries of social space: "A post-structuralist approach to radical democracy supports a version of what, rather tellingly, Balibar calls a 'politics of civility', an effort to bring the margins back into public life by extending civil discourse to those who live beyond its frontiers" (Martin 2009, p. 106). Here, the polyphonic character of civil society is stressed, the fact that it contains a multiplicity of voices, also those excluded from other fora (Goldstein 2016; Korolczuk 2011; Jacobsson and Saxonberg 2013; Jacobsson 2015).

We conceptualize civil society in broad terms as part of society where non-governmental actors (including the sphere of associations, the intimate sphere, social

\footnotetext{
${ }^{4}$ This is true for the post-structuralist version of radical democracy referred to here, and for a critical theoretic version formulated most prominently by Jürgen Habermas (1996, see also Jezierska 2011). Habermas has famously argued that deliberative opinion and will formation take place in a variety of formal and informal publics, situating weak deliberation in the realm of public sphere, which he treats as akin to civil society (see also Cohen and Arato 1992; Martin 2009).
} 
movements, and forms of public communication) are mobilized and engaged in influencing existing social and political orders, in this way being the "locus of the potential expansion of democracy" (Cohen and Arato 1992 , p. viii). It is a field of society where institutionalized and non-institutionalized forms of collective action are included (Polanska and Chimiak 2016), and our empirical material is a good example of links between these two. The radicalism of civil society is merely a potential, while many parts of civil society play a consolidating function for the existing system (e.g., Jezierska 2015).

Social movements usually belong to the less formalized part of civil society, but sometimes also collaborate with more stable structures of formal associations in various ways. According to the conception applied here, and following the European tradition of social movement studies (e.g., Melucci 1995; della Porta and Diani 1999), we focus more on the processes of identity formation and re-articulation of claims in a changing political opportunity structure, rather than on a resource mobilization model. As noted above, social movements, more or less directly, have an orientation at transforming social relationships rooted in the passions, grievances and demands they mobilize. Obviously not all social movements are automatically "radical." "'Radical' social movements would be those that seek change at what they consider to be the 'root' level of one or more social antagonisms: radical feminists seeking to eradicate patriarchy, radical socialists seeking to eliminate capitalism, radical environmentalists seeking to end the domination of nature" (Day 2004, p. fn. 1). However, as mentioned above, challenges to the status quo can only be articulated by resorting to the vocabulary currently in use. Moreover, even movements not targeting the root level can add up to a piecemeal struggle changing the basis of socio-political organizations. This is in line with Laclau and Mouffe's program of hegemonic re-articulation and not revolution (Robinson and Tormey 2009, p. 133). They argue that within the framework of the liberal state, current power relationships can be questioned, and the stability of today's truths and beliefs can be shaken.

Analyzing social movements by connecting them to the concept of civil society and radical politics provides us with a broader contextualization of the particular movement. As civil society captures even other spheres of social interaction outside of institutionalized politics that are not only described as social movements, the picture of the conditions under which a particular social movement functions grows somewhat wider. The political context of a particular civil society will inform us about the constraints and opportunities the analyzed social movement faces in challenging or rearticulating hegemonic discourses.

\section{The Political Context in a Central European Country}

The context of post-state-socialist Central Europe is crucial for understanding the conditions under which the studied social movement operates. In a number of recent publications, authors have shown how the neoliberal orientation in economy and politics gained ground in the region (Ost 2000; Stenning et al. 2010; Woś 2014; Shields 2007, 2015). Embraced by practically all political parties and many other social actors, neoliberalism has won a hegemonic position: "left and right have been (willingly) co-opted into the reproduction of neoliberalism" (Shields 2015, p. 660). The period after 1989 in Central Europe is characterized by a "turn to market," deregulation, decentralization, and withdrawal of the state. Stenning et al. (2010) argue that neoliberal economic ideas were not "new" in the region in the 1990s, but were shared and actively discussed in the area already in the 1980s, and sometimes even earlier. After 1989 most of the introduced reforms, policies, and programs leaned on neoliberal ideas that were promoted by a wide variety of actors including "local think tanks, policy makers, political parties, and trade unions" (2010, p. 39). In the case of Poland, even the Solidarity movement, largely contributing to overthrowing the former system, supported the neoliberal reforms (Ost 2000), despite their guiding principles of "worker self-government; self-management, and the "self-liberation of civil society" (Shields 2007, p. 156). Ost argues that Solidarity facilitated the neoliberal agenda by "winning workers over to neoliberalism" as the movement decided to abstain from striking during the first 2 years of the Shock Therapy ${ }^{5}$ in the country (Ost 2000, p. 514).

The response of civil society to the extensive neoliberal practices and ideas in Poland has been described as "moderate reformism," a type of neoliberal consensus that was shared by civil society along with the country's leading politicians and economists (Ekiert and Kubik 2014). However, more recently, at least since the early 2000s, an increasing number of populist and right-wing mobilizations has been taking place along growing discontent among the population. This "caused researchers to pose questions of 'an end to patience' in the second round of economic hardships among the post-socialist populations" (Polanska 2016, p. 1, see also Beissinger and Sasse 2013). The extent of this new trend, or nascent opposition to the neoliberal consensus calls for empirical examinations. In virtual absence of a publicly expressed leftist critique of the neoliberalization processes, it is especially interesting to study how movements formulate their demands, which

\footnotetext{
5 "Shock Therapy" refers to the period after 1989, characterized by offensive economic liberalization.
} 
explicitly challenge the status quo and can thus be seen as an attempt at creating a counter-hegemonic position.

The political context in Central Europe is further characterized by only some specific forms of mobilization being labeled acceptable: "those which are non-violent, 'civilized', 'cultured', 'rational' and seeking cooperationrather than conflict-with state and market actors" (Gagyi and Ivancheva 2014, p. 4; see also Jezierska 2017). Moreover, Cisař writes that radical left organizations in post-socialist settings operate outside of what is seen as socially acceptable and "are unable to get any resonance for their anti-capitalist demands discredited by the former Communist regimes" (2013, p. 997). This obviously does not mean that protest politics are absent in Central Europe. As Ekiert and Kubik (1999) have shown, contentious or rebellious actions were frequently undertaken in Poland after the regime shift in 1989. However, these protests were rather moderate in character and were not intended to reverse the trajectory of changes after 1989 but to protest specific policies of the government.

The activities of civil society actors, as we documented, were increasingly contentious; protests became a salient feature of the newly democratized polity. At the same time, protest strategies were largely nonviolent, demands put forward by protest organizers usually moderate, and their rhetoric only infrequently antisystemic and inflammatory. (Ekiert and Kubik 1999, p. 193, emphasis in original)

What the above quote alludes to, and what distinguishes the Polish context from the context in Western Europe, is the political culture and its traditional norms. The political culture in Poland is still greatly guided by the norm and tradition of non-violence (to be traced to the emergence of non-violent protests in the 1980s, and later on the Solidarity movement's non-violent repertoire) (Modzelewski 1982), and the already mentioned "self-implied moderation" of the working classes (Ost 2000).

\section{Tenants' Movement in Poland}

There are more than 40 associations (stowarzyszenia) of tenants registered in Poland today. Many more work in an un-institutionalized fashion, without the legal form of an association. This combination and collaboration between more and less formalized types of organizations highlights the hybrid structure of the tenants' movement, which is situated both within and without the third sector. Most large and middle-sized Polish cities have at least one registered tenants' association, and the most numerous and vivid ones are found in the capital city, Kraków, and Poznań. Polish tenants' mobilization is of profoundly urban character, taking place in cities and addressing urban issues. The first tenants' association, after the fall of state socialism, was founded in 1989. In the 1990s many associations were founded as a reaction to privatization processes going on in the country and the vast majority of these associations cooperated with real estate owners' organizations in what by then was called the National Housing Movement (formed in 1991). This period in the tenants' movement's development can be labeled "adaptation of the neoliberal logic" (Polanska 2016), due to the movement's coalitions with real estate owners and the collective claims formulated by them, directed at improving the legal situation and clarifying property rights in the country.

Tenants' associations were founded all over the country in the 2000s, and during this period tenants came to redefine their adversary as "capitalism." This re-definition was partly a result of changes in policies, the final letting go of the 10-year rent-freeze in the country and a reaction to rising rents and accelerating re-privatization processes. Tenants' previous allies, real estate owners, were from now on perceived as enemies and representatives of the unjust capitalist system. There were countless conflicts between tenants and real estate owners, and lawsuits succeeded one another in this period. From harsh critiques of the legal system's shortcomings in the 1990s, the focus was shifted toward the Polish social welfare system and its poor development, in particular the inability of the state to provide affordable public housing. The role of the state in leveling out inequalities was emphasized by the tenants in this period, and local authorities were accused of implementing "wild capitalism" (dziki kapitalizm) (Kotomski 2012).

In 2004, a campaign called "Housing is a human right, not a commodity" (Mieszkanie prawem, nie towarem) gathered tenants, anarchists, and leftist organizations in Warsaw under the claims of improved tenants' rights against "the liberal politics-commercializing social housing and depriving a large number of people of their right to housing" (Smosarski 2007, p. 32). A turn toward more contentious repertoires of action among the tenants was observed in the years after 2011 (Polanska and Piotrowski 2015).

At the same time, tenants' struggles were widely perceived as illegitimate as they did not entirely fit the category of the "right" kind of mobilizations due to the causes and nature of their claims in criticizing state and municipal policies, questioning property rights, demanding "affordable" housing and using direct methods or civil disobedience as action repertoires. Polanska (2017) demonstrated Polish tenants' movement's marginalized position in the dominant discourse in her study of tenants' activism's delegitimization in Poland by depicting tenants as immoral and unwilling to pay rents, as passive objects that should be 
dealt with, or as victims. According to this dominant discourse, tenants are seen as remnants of the old system with outdated demands. The Polish context is harsh on tenants, tenants' activism is seen as unconventional, and repressive eviction measures are applied. Tenants are recurrently harassed, and the attitude of local authorities and civil servants is described as unhelpful and unsympathetic (Polanska 2017; Audycka-Zandberg 2014; Urbański 2010).

\section{Radical Politics of Tenants}

The analysis in this article focuses on the more recent development in the tenants' movement in Poland, i.e., starting approximately in 2011 and their turn to more contentious demands and forms of action. The year 2011 marks an important change in the discourse on tenants in the media when the murder of the founder of Warsaw's Tenants' Association was widely covered (cf. Polanska 2017). We believe that this tragic event publicized the situation of tenants in the country and influenced tenants to articulate their claims in a more explicit way. It also sparked closer collaboration between tenants and, for instance, squatters.

The analysis is structured according to the main themes in the radical political framework discussed above. First, the interplay between equivalence and difference, i.e., the two logics providing unifying and dividing tendencies in social movements, is discussed. Here, two specific claims have been helpful in conceptualizing the different aspects of tenants' struggle_claims to recognition and redistribution. Under this theme we also examine the equalizing work of a symbolic unifier that helped bring together different collective actors engaged in housing issues. The second theme of the analysis circles around the process of identity formation. We trace how a collective "we" of tenants solidified through identification of concrete and abstract Others. The third and final theme focuses on (re)articulation of demands. We present this process as an effect of the two previous themes (the interplay between equivalence and difference and definition of a "we" in opposition to an Other), as well as some exogenous factors that the movement did not control, but readily responded to. Taken together, these aspects of the radical political framework help us give a comprehensive picture of the processes of re-definition of a movement as an effect of internal and external developments.

\section{Logics of Equivalence and Difference}

There are many differences between the Polish tenants' and squatters' movements, both with regard to the organizational structure (squatters having a flatter, looser organization, and tenants having a formalized organization with coordinating organs and leaders), and specific characteristics of activists (social background, motivations, ideological profile, and preferred repertoire of actions). However, these differences have been deliberately underarticulated by the tenants in the last few years, giving way to cross-fertilization between possible common issues, in particular repertoires of action and political claims. Here, one tenant activist comments on the considerable age difference between tenants and squatters, which nevertheless does not impede mutual admiration and practical support expected of each other.

I admire these people [squatters], I need to admit. I admire them because they are young people that sacrifice their free time for cultural activities for children or for organizing foreign language classes. They do a lot. You can always count on them. Whenever we need their help, if it is about a poster, or something else, they never deny us. They are upto-date with tenants' issues. They always join us whenever we need them. I simply admire them. I have very good contact with them, even if I call them the "third generation". First there is me, then there is my son, and then the grandchildren. And they are children, for me they are children, and so are you. I have kids older than this, they are in their 40s. (T10)

The differences between tenants and squatters were also seen by the tenants as strengthening and complementing their struggle to some extent. Here are the words of a tenant activist when talking about the links between tenants' issues and squatting:

I would definitely include it [squatting] in the tenants' movement. All the more since a great movement is taking place at the squat. It makes you think. However, I think that squatters add some freshness and fast acting. Besides, they have a similar action structure, I don't know how to call it. It is a kind of incident, quick organization, action, or something like the blocking of an eviction, it complements perfectly here. (T14)

The use of direct action as a method was emphasized as a similarity between tenants and squatters. Some of the interviewed tenants shared similar attitudes toward the authorities with squatters, where confrontation was sought rather than dialogue.

Since 1989, and especially during the 1990s, tenants' activism has revolved around claims of redistribution, i.e., targeting the legal, political, and economic aspects of public housing in Poland. Since the 2000s, tenants demanded improvement of their housing situation and acceptance of their position as tenants. Squatters mostly 
mobilized their actions around demands for recognition, claiming acceptance of a specific lifestyle and cultural expression. Recognition and redistribution have been defined as "refer[ring] not to philosophical paradigms but rather to folk paradigms of justice, which inform presentday struggles in civil society" (Fraser 2003, p. 11, emphasis in original). Fraser argues that these are often, and misleadingly, cast as mutually antithetical, while they co-appear in most social movements. Here, while not denying the fact of their intertwinement, they are treated as a heuristic tool to make sense of the outspoken claims of the studied movement. Most important for our account is that claims to redistribution and recognition are based on different conceptions of injustice.

The redistribution paradigm focuses on injustices it defines as socio-economic and presumes to be rooted in the economic structure of society. [...] The recognition paradigm, in contrast, targets injustices it understands as cultural, which it presumes to be rooted in social patterns of representation, interpretation and communication. (ibid., p. 12-13)

In effect, the paradigms propose different remedies: economic restructuring of some sort versus cultural or symbolic change.

Even if the issues that mobilized the tenants to act collectively were not very explicit to begin with, their more recent articulation of claims has mixed these aspects, where their critique on housing and wealth redistribution in Poland is combined with the recognition and legitimation of their claims by attempting to influence political and media discourses. The tenants were united by the feeling of injustice, and being excluded from meaningful democratic participation. Here, one of the tenants describes how their struggle is being censored by the national media:

I'll give you an example. I received a call from a woman at Gazeta Wyborcza [main Polish daily]. She has material on my client [tenant] and she is crying about her wanting to quote me, but it is not allowed by Gazeta Wyborcza. Why? It is not hidden censorship, it is open and arrogant. It is an obstacle and it confirms the fact that our opponents are not stupid, they are afraid that it will be revealed, that they are wrong, that they are on the wrong side, that everything they say is a lie, and so on. (T8)

The interviewed tenants' activist referred to the censorship of opinions coming from the left in the newspaper. This quote reminds us of the illegitimate position that "leftist" ideas and representatives are given in the post-socialist, and neoliberal, contexts.

The tenants, clearly marginalized by the mainstream media discourse, claimed recognition of their claims in the public discourse, and realized that their voice becomes stronger when combined with the demands of other housing activists disprivileged in the Polish housing system. In an attempt to be heard as one consolidated voice, the movement needed to "create a chain of equivalence among the various democratic struggles against different forms of subordination" (Laclau and Mouffe 2001, p. xviii). One unifying claim became the statement, "Housing is a human right, not a commodity," that was raised in a campaign initiated by anarchist and leftist organizations in 2004 and aimed at facilitating self-organization among tenants. Housing activists and tenants stood united behind this slogan and the cooperation in the campaign aimed at fighting "for the rights of tenants and the development of public housing construction, along with opposing the attempts at commercialization of the Polish housing sector" (Lokatorzy.pl). This claim was further articulated in the period after 2011. Some external mechanisms influencing this sharpening of claims in the tenants' movement, or more broadly the Polish housing movement-including tenants, squatters, and other groups disprivileged in the housing sphere-were the financial crisis that deepened the processes of flexibilization and precarization of the labor market and the continued growth of right-wing mobilization and rhetoric in the country (Beissinger and Sasse 2013; Ekiert and Kubik 2014) combined with accelerated reprivatization processes during this period.

Apart from linking the claims of redistribution and recognition into one chain of equivalence, the sense of being united for a common cause and speaking in one voice was strengthened by invoking a symbolic unifier. Such a unifier was found in the figure of Jolanta Brzeska. She was the founder of the Warsaw Tenants' Association, who was brutally murdered in 2011, and has since become an icon for the tenants' movement and other housing activists in the country. She was burned to death and found in the outskirts of Warsaw, and one of the slogans used commonly by the tenants and housing activists in the recent years has been "You will not burn us all" (Zubik and Machajski 2011) (see Fig. 1). By the time Brzeska was murdered she was living in a privatized tenement house refusing to move out. The activists believe that she was murdered due to her activism and resistance to move out of the building. The murder of Brzeska resulted in common actions of tenants and squatters, pointing to the capitalist system for creating favorable conditions for developers and authorities to profit from vulnerable groups. In a common initiative, "Justice for Jola Brzeska," city authorities were described as representing "not the people but the interests of speculators, whose money speaks louder than the needs of the city's residents" (JolaBrzeska.wordpress.com).

Re-privatization processes, where former municipal tenants are involved, have been recurrently reported in the 


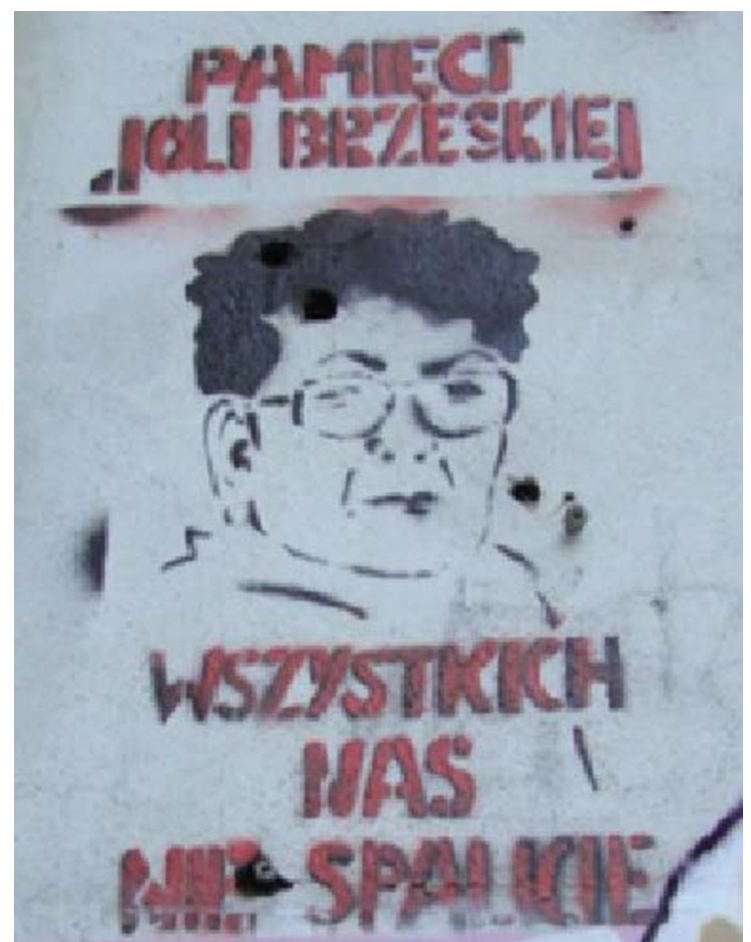

Fig. 1 Stencil art of Jolanta Brzeska stating "To the memory of Jola Brzeska. You will not burn us all"

media for violent and harassing methods of getting rid of the sitting tenants (Kretkowski 2011). This uncontrolled side of privatization, where ordinary people are bereft of their rights, sparked the particular collaboration between tenants and squatters. It became even more urgent after 2013, when two Warsaw squats were attacked during the annual Independence March and a group of nationalists/ right-wing activists tried to set them on fire. The slogan of "You will not burn us all" gained another dimension after these attacks. It was no longer solely directed against capitalist expropriation, but also against fascist and rightwing ideologies, aligning the socioeconomic with the symbolic dimensions.

Worsening conditions in the country and the activity of different collective actors in the field of civil society, as well as the empowering experience of alliance building, were described by the interviewed activists as a dormant potential, awaiting awakening:

There are different levels of social organization, and squatting movement is a very engaged movement in tenants' issues. They are actively taking part in blockades of evictions. And it is a sort of magma, taking place on different levels of activity in the country right now. At what point in time the volcano will explode is difficult to predict. (T13)

\section{Constructing a "We" in Opposition to the Other}

The chain of demands was further solidified by pointing out common Others. As Marcuse explains, the claims of recognition and redistribution are linked through reference to a common enemy: "Thus the culturally alienated and the immediately deprived have a common enemy. And that is increasingly recognized, even if its name is not always the same: capitalism, neoliberalism, greed, multinationals, power elite, the bourgeoisie, the capitalist class" (Marcuse 2009, p. 195). The interviewees point out concrete Others, such as politicians, real estate owners, civil servants and representatives of the justice system, who are all described with a list of undesirable, repulsive and immoral attributes and behaviors. Among the concrete Others, the category of civil servants is pointed out as exceptionally unsympathetic and immoral. Civil servants responsible for implementing housing policies are described as appointed to help in redistributing material resources, but their attitudes and practices toward tenants instead classify them as enemies:

They completely don't give a damn. They despise these people [tenants]. They consider them to be worthless. Can they really realize their legal obligations to satisfy these people's housing needs? How can they do that if they consider these people to be worthless? (T1)

Several protest actions held in 2016 were motivated by the attitudes of civil servants toward tenants. These attitudes were described in the following way on the webpage of the Committee for the Defense of Tenants' Rights:

The systematic ignorance of tenants' needs by civil servants in housing provision departments and district councils was the direct cause of the protest. It is evident in the provision of uninhabitable dwellings (fungus, lack of bathrooms) or the disqualification from renting to persons fulfilling all the criteria.

The protest actions were deliberately intended not only as voicing discontent, but also as a conscious effort to shape a collective identity:

We see the cycle of actions as very successful, above all because of the improvement of the participants' morale, finally experiencing that they can succeed in making their voices heard. (Lokatorzy.info.pl 2016-06-22)

The sense of "we" includes a shift from the marginalized and powerless image spread by public officials and the media to identification as self-determining agents and active actors taking the housing issue in their own hands. Through collective action tenants realized they have a voice and demanded to be listened to. In this sense the 
Fig. 2 Tenants demonstrating against the "anti-social municipal politics." Photograph: Komitet Obrony Praw Lokatorów

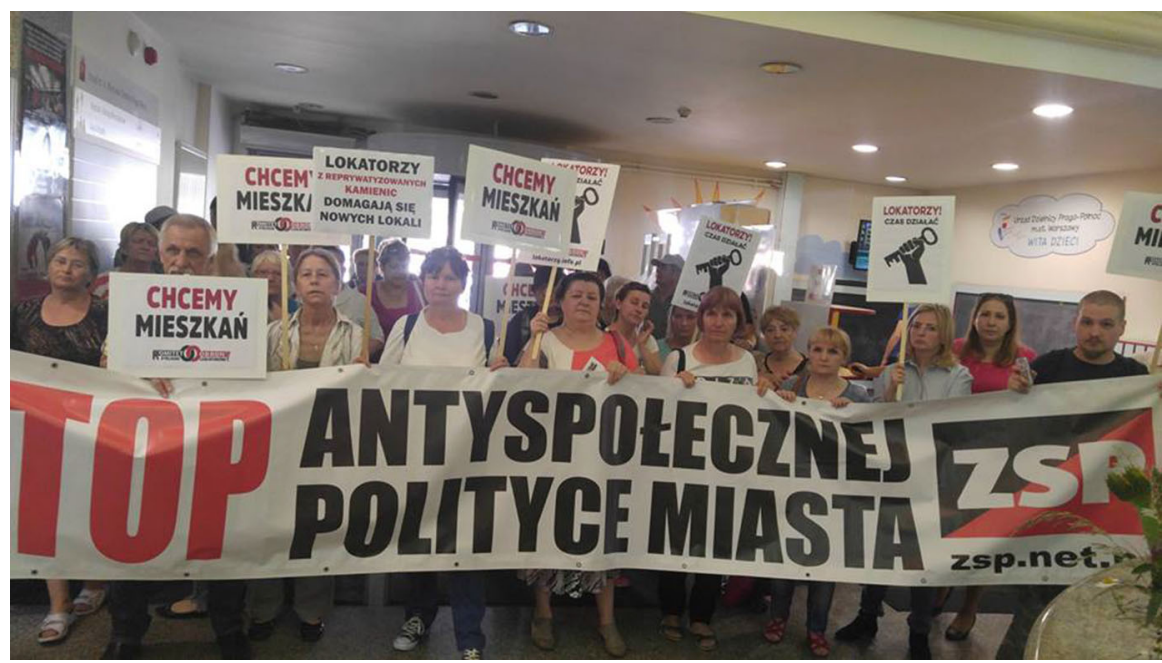

protests had a clear empowering role, spurring the process of subjectification. The focus of several of the actions pursued in 2016 was what the tenants call the "anti-social municipal politics," consisting of the unjust treatment of tenants by civil servants, the lack of interest of politicians and the lack of discussion on city level on the situation and needs of tenants in municipal and re-privatized housing stock (see Fig. 2).

Apart from the concrete Others, the enemies were identified on a more abstract level, in the oppressive forces of capitalism, illustrated in the processes of privatization of housing. Lately a new term, "gentrification," has entered the analysis of the situation and has been used by the tenants to criticize urban renewal plans that in the end lead to displacement of tenants. However, the process of identifying the more abstract forces among tenants is described as slow:

But slowly, because it is a process, they become more interested [in more abstract explanations] than the more direct issues. Why don't I have an apartment? Because if it is caused by the fact that no apartments are being built, who is making these decisions? It awakens people's curiosity in itself and they are looking for answers for this kind of problem. (T7)

The critique of the neoliberal orientation in the housing policy and the capitalist system was sometimes made more tangible in the categorization of its representatives. Interviewees depicted a common enemy in the individuals and companies that have made a profitable business of buying/claiming housing property from the municipality/former owners, raising the rents so that the majority of the sitting tenants could not afford staying or harassing the tenants so they would leave. One good example is the case of a private developer who appeared in 2012 as street art on a wall of a building in Warsaw with a canister stating
"Warsaw is flammable" (Erbel 2012), referring to private owners getting rid of tenants by setting fire on buildings and the very murder of Jolanta Brzeska in 2011.

The Committee for the Defense of Tenants' Rights even used the metaphor of a "class war" to describe the situation in the district of Warsaw where the association is opposing gentrification:

Again we have to deal with the cleaning of Praga [district in Warsaw] from the local community. The elite of this city want to invade our neighborhood and have other activities there, other people. They abuse their authority to carry out a class war against those worse off. (Lokatorzy.info.pl 2016-09-26)

The authorities were described with wording closely associated with war and violence unlawfully using their position to displace tenants' communities. Tenants were depicted as organic parts of the local communities who are forced to leave them as a result of the interests of the stronger groups in society-the local elite.

\section{(Re)articulation of Demands}

The articulation of new claims was an effect of external forces, not entirely controlled by the movements. The opening up of local authorities for the talks with tenants in a "Housing Round Table" was an opportunity that appeared after a relatively large demonstration in 2012, where tenants and squatters stood unified vis-à-vis the authorities to protest the eviction of one of the city's squats. The linking of the claims of recognition and redistribution into one chain surprised the municipalities, which found this new platform challenging. Here are the words of one of the tenants' activists: 
There was a manifestation that was quite big in Warsaw, and I think that the authorities got scared. I think that there was nothing like that before, and it was indeed very numerous. [...] It is thanks to squatters that postulated the condition on the housing round table, and therefore it is now taking place. (T1)

On behalf of the tenants, one of their key concrete demands in 2012 was to re-initiate the talks with city authorities on housing policy in the city.

Later on the demonstration on the streets of Warsaw [in 2012] about the social injustices caused the coming-back of the so called "Housing Round Table". We could say that we have been for a while now talking with the vice-president of Warsaw, Michal Olszewski, about the housing and tenants' issues. (T15)

The identification of abstract others as the antagonist enabled a widening of cooperation patterns. Not only squatters, but also trade unions were seen as allies against the neoliberal policies and the capitalist system. Tenants aligned forces with workers, and tenants' rights were propagated side by side with workers' rights. During a May Day demonstration in 2016 one of the largest tenants' associations, the Social Justice Office, gathered around following slogans:

Stop giving back townhouses with tenants!

Cancel usurious loans!

Punish rogue judges, prosecutors, bailiffs, notaries and police officers!

Build public housing with low rents!

Give prison-sentences for not paying salaries!

(Facebook.com event 1560292397618544)

This re-articulation of demands has been even more explicit since the latest parliamentary elections in 2015 and the conservative party Law and Justice success in the election. Different threats associated with the new government have resulted in new claims of the Polish tenants' movement. For instance, when the new government questioned the work of Poland's human rights' plenipotentiary in 2016, one representative of a tenants' association explained:

The government has in its offer to the citizens of a much needed and important program [referring to the housing program mieszkanie plus] forgotten the fact that, in accordance with the constitutional principles of social solidarity and social justice, public aid must in the first place be directed to the poorest, because their rights are most at risk, especially in the context of the right to housing. (Nosal-Ikonowicz 2016-0909)
It is evident since the latest parliamentary election that the changes implemented by the new government along with perceived potential threats have sharpened the articulation of tenants' claims. The articulated problem is no longer only the problem of the provision of housing in general, but also issues concerning workers, low-income households, and those lacking economic means. Their struggle is also described as targeting corrupt elites (politicians, civil servants, representatives of the justice system, and so on) and a system that "censors and blames the poor" (Polsat 2016-10-08).

Obviously, processes of forming a chain of equivalence are not entirely rational, planned actions. This is quite visible in the articulation of tenants' claims. Due to a series of external events and political openings, tenants have been able to rearticulate and expand their claims and demands, which led to a shift in their self-understanding. Apart from deliberations and negotiations of common strategies of action, tenants sometimes broadened their slogans to include the rights of other groups (be it workers, poor, disabled or single mothers) and engaged in actions supporting tangential struggles, thus forming a broader front. The various collective actions described above often resulted in a feeling of mutual respect, and admiration. Above all, an increased sense of empowerment and agency significantly changed the identity of the tenants' movement.

\section{Conclusions}

This article aimed at studying processes of identity and claim formation in a social movement with the help of the radical political framework. We stressed the importance of contextual opportunity structures, the background symbolic and material factors, for the understanding of these processes. The specific Central European context conditions both the range of possible claims and available repertoire of actions and by connecting to the concept of civil society in our analysis we outlined the conditions under which the Polish tenants' movement functions with strong norms of "moderation," "collaborative and civil behavior," and "non-violence" (Gagyi and Ivancheva 2014). The shape of Polish civil society and the political culture demonstrated existing constraints and opportunities to challenge or rearticulate the hegemonic discourse of neoliberalism. In the face of the neoliberal hegemony the tenants' movement adjusted its claims, targeting both the abstract capitalist mode of economy and the concrete municipal strategies applying the neoliberal logic, including gentrification.

The chosen case of the tenants' movement in Warsaw exemplified the formation of a piecemeal counter-hegemonic position. While initially the movement can be 
described as representing demands of redistribution and an internalized identity of a weak subject, the claims of recognition became more and more apparent and led to forming a chain of equivalence between these claims. The threats coming from the outside (housing policies, processes of gentrification, displacement, and stigmatization of tenants) highlighted the need of simultaneous work on both fronts-economic restructuring and symbolic change. Here the collaboration with squatters and other marginalized social movements was instrumental. The common struggle against the municipality provided a wider spectrum of experiences, expertise, and networks. Collaborations with other housing activists and trade unions, even though not friction-free, were mostly a question of positive cross-fertilization. Some demands were rearticulated, evolving into a common position and thus shifting the selfdefinition of the tenants' movement.

Helpful in the process of alliance formation was the process of identifying common Others, both concrete, embodied by civil servants, politicians or developers, and abstract, such as the capitalist system and neoliberal policies regarding public housing and wealth redistribution. Another unifying factor was provided by the iconic figure of Jolanta Brzeska, portrayed as a martyr in the struggle for justice.

While the literature on social movements to some extent already incorporates insights from a radical political perspective, this article attempted to gather the different concepts into one coherent framework. We applied the theoretical framework of radical politics to examine processes of demand and identity formation of a social movement that is often pictured as radical in an attempt to delegitimize its struggle. The purported radicalism of the Polish tenants' movement is closely related to local, Central European perceptions of how a normal and "accepted" social movement should be and act. The very fact of mobilization of a socially and economically deprived group is provocative in the Central European context. Activism and mobilization of "losers" of Shock Therapy is therefore deemed radical. In this article we attempted an evaluation with the tools of the Laclau-Mouffean framework the extent of radicality of the tenants' movement. The theory of hegemony, pointing to the two logics of interaction (equality and difference), the mechanism of chain formation between different types of struggles and re-articulation of demands and identities as a result of that process, provided us with theoretical and methodological tools of assessing the radicalism at stake. The studied tenants' movement has managed to target the root causes of their underprivileged situation systematically. By linking socioeconomic and symbolic issues into one common struggle, the hegemonic position of the neoliberal mode of economy and politics is addressed. In that sense, the movement succeeded in identifying the root causes of the experienced marginalization, thus fulfilling the criterion for a radical movement. This particular mobilization of tenants in Warsaw is obviously not strong enough to form a viable threat to the neoliberal hegemony, but it might nevertheless be seen as one of the local signs of punctuation of the neoliberal mode of transition.

Acknowledgements We would like to thank all the activists interviewed for this study and especially those who took their time to comment on our work at different stages of writing the paper. We are also grateful to the Baltic Sea Foundation and the Swedish Research Council as well as the Institute for Housing and Urban Studies, Uppsala University and Centre for European Research, University of Gothenburg for financial and intellectual support.

Funding This study was funded by The Swedish Research Council (i.e., Vetenskapsrådet) (Grant No. 350-2012-309) and Baltic Sea Foundation (Grant No. 2185/311/2014).

\section{Compliance with Ethical Standards}

Conflict of interest The authors declare that they have no conflict of interest.

Ethical Standards This article complies with the ethical standards set by the Journal.

Open Access This article is distributed under the terms of the Creative Commons Attribution 4.0 International License (http://crea tivecommons.org/licenses/by/4.0/), which permits unrestricted use, distribution, and reproduction in any medium, provided you give appropriate credit to the original author(s) and the source, provide a link to the Creative Commons license, and indicate if changes were made.

\section{References}

Audycka-Zandberg, B. (2014). Warunki $i$ strategie mobilizacji najemców lokali mieszkalnych $w$ stowarzyszeniach lokatorskich [Conditions and Mobilization Strategies among Renters in Tenants' Associations]. Warszawa: Uniwersytet Warszawski.

Beissinger, M. R., \& Sasse, G. (2013). An end to 'patience'? The great recession and economic protest in Eastern Europe. In N. Bermeo \& N. Bartels (Eds.), Mass politics in tough times: Opinions, votes and protest in the great recession. New York: Oxford University Press.

Brown, W. (2015). Undoing the demos: Neoliberalism's stealth revolution. New York: Zone Books.

Císař, O. (2013). Post-communism and social movements. In D. Snow, D. Della Porta, B. Klandermans, \& D. McAdam (Eds.), Encyclopedia of social and political movements (Vol. 3, pp. 994-999). London: Blackwell.

Cohen, J., \& Arato, A. (1992). Civil society and political theory. Cambridge: MIT Press.

Della Porta, D., \& Diani, M. (1999). Social movements: An introduction. Oxford: Blackwell.

Diani, M. (1992). The concept of social movement. The Sociological Review, 40(1), 1-25.

Escobar, A. (1992). Imagining a post-development era? Critical thought. Development and Social Movements. Social Text, 31(32), 20-56. 
Day, R. J. F. (2004). From hegemony to affinity. Cultural Studies, 18(5), 716-748.

Ekiert, G., \& Kubik, J. (1999). Rebellious civil society. Popular protest and democratic consolidation in Poland, 1989-1993. Ann Arbor: University of Michigan Press.

Ekiert, G., \& Kubik, J. (2014). Myths and realities of civil society. Journal of Democracy, 25(1), 46-58.

Fraser, N. (2003). Social justice in the age of identity politics: Redistribution, recognition, and participation. In N. Fraser \& A. Honneth (Eds.), Redistribution or recognition? A politicalphilosophical exchange. London: Verso.

Gagyi, A., \& Ivancheva, M. (2014). Introduction. In S. Saleri \& A. Valera (Eds.), Civil society in Central and Eastern Europe: What's left of it?. Cluj-Napoca: European Alternatives.

Goldstein, P. (2016). Everyday active citizenship the Balkan way: Local civil society and the practice of 'Bridge Building' in two post-Yugoslav Cities. In U. M. Vieten \& G. Valentine (Eds.), Cartographies of differences: Interdisciplinary perspectives (pp. 135-154). Oxford: Peter Lang.

Gramsci, A. (1971). Selections from the prison notebooks of Antonio Gramsci. Q. Hoare, and G. Nowell Smith (Ed. \& Transl.). London: Lawrence and Wishart.

Habermas, J. (1996). Between facts and norms. Contributions to a discourse theory of law and democracy. Cambridge: MIT Press.

Howarth, D., Norval, A. J., \& Stavrakakis, Y. (Eds.). (2000). Discourse theory and political analysis: Identities, hegemonies and social change. Manchester: Manchester University Press.

Jacobsson, K. (Ed.). (2015). Urban grassroots movements in Central and Eastern Europe. Farnham: Ashgate.

Jacobsson, K., \& Saxonberg, S. (2013). Beyond NGO-ization. The development of social movements in Central and Eastern Europe. Farnham: Ashgate.

Jezierska, K. (2011). Radical democracy redux. Politics and subjectivity beyond Habermas and Mouffe. Örebro: Örebro University Press.

Jezierska, K. (2015). Moral blueprint or neoliberal gobbledygook? Civil society frames among Polish think tanks. East European Politics and Societies, 29(4), 831-849.

Jezierska, K. (2017). Defining in/defining out. Civil society through the lens of elite NGOs. In K. Jacobsson \& E. Korolczuk (Eds.), Civil society revisited: Lessons from Poland. New York: Berghahn Books.

Koopmans, R. (1993). The dynamics of protest waves: West Germany, 1965 to 1989. American Sociological Review, 58, $637-658$.

Koopmans, R., \& Statham, P. (1999). Political claims analysis: integrating protest event and political discourse approaches. Mobilization: An International Quarterly, 4(2), 203-221.

Korolczuk, E. (2011). Kłopot z NGOizacją: Debata na temat społeczeństwa obywatelskiego w Polsce [The Problem with NGO-ization. The Debate on Civil Society in Poland]. Polityka Spoteczna, 5-6, 37-43.

Kretkowski, K. (2011). Wptyw procesów reprywatyzacyjnych $w$ Warszawie na sytuacje materialna mieszkańców $w$ latach 2000-2010 [The Influence of Reprivatization Processes on the Material Situation of Residents of Warsaw in 2000-2010]. Uniwersytet Warszawski: Wydział Geografii i Studiów Regionalnych, MA Thesis.

Kriesi, H. (2004). Political context and opportunity. In D. A. Snow, S. A. Soule, \& H. Kriesi (Eds.), The blackwell companion to social movements. Malden, MA: Blackwell.

Laclau, E. (2005). On populist reason. London: Verso.

Laclau, E., \& Mouffe, C. (2001[1985]). Hegemony and socialist strategy: Towards a radical democratic politics. London: Verso.

Marcuse, P. (2009). From critical urban theory to the right to the city. City, 13(2-3), 185-196.
Martin, J. (2009). Post-structuralism, civil society and radical democracy. In A. Little \& M. Lloyd (Eds.), The politics of radical democracy. Edinburg: Edinburg University Press.

McCormick, J. (1989). The global environmental movement: Reclaiming paradise. London: Belhaven Press.

Melucci, A. (1995). The process of collective identity. In H. Johnston \& B. Klandermans (Eds.), Social movements and culture (pp. 41-63). Minneapolis: University of Minnesota Press.

Melucci, A. (1996). Challenging codes: Collective action in the information age. New York: Cambridge University Press.

Modzelewski, W. (1982). Non-violence and the strike movements in Poland. Journal of Peace Research, 19(2), 107-116.

Mouffe, C. (1993). The return of the political. London: Verso.

Mouffe, C. (2005). On the political. New York: Routledge.

Mouffe, C. (2008). Critique as counter-hegemonic intervention. Transversal multilingual webjournal. Vienna: European Institute for Progressive Cultural Policies. Retrieved July 7, 2015, from http://eipcp.net/transversal/0808/mouffe/en/print.

Mouffe, C. (2013). Agonistics. Thinking the world politically. London: Verso.

Norval, A. (2000). Trajectories of future research in discourse theory. In D. Howarth, A. Norval, \& Y. Stavrakakis (Eds.), Discourse theory and political analysis. Identities, hegemonies and social change. Manchester: Manchester University Press.

Ost, D. (2000). Illusory corporatism in Eastern Europe: Neoliberal tripartism and postcommunist class identities. Politics and Society, 28(4), 503-530.

Polanska, D. V. (2016). Neoliberal post-socialist urban transformation and the emergence of urban social movements in Poland. In M. Mayer et al. (Eds.), Urban uprisings: Challenging neoliberal urbanism in Europe. New York: Palgrave Macmillan.

Polanska, D. V. (2017). Marginalizing discourses and activists' strategies in collective identity formation: The case of polish tenants' movement. In K. Jacobsson \& E. Korolczuk (Eds.), Civil society revisited: lessons from Poland. New York: Berghahn Books.

Polanska, D. V., \& Chimiak, G. (2016). Organizing without organizations: on informal social activism in Poland. International Journal of Sociology and Social policy, 36(9/10), 662-679.

Polanska, D. V., \& Piotrowski, G. (2015). The transformative power of cooperation between social movements: the case of squatting and tenants' movements in Poland. City: Analysis of Urban Trends, Culture, Theory, Policy, Action, 19(2-3), 208-230.

Polletta, F., \& Jasper, J. M. (2001). Collective identity and social movements. Annual Review of Sociology, 27, 283-305.

Prentoulis, M., \& Thomassen, L. (2013). Political theory in the square: Protest, representation and subjectification. Contemporary Political Theory, 12, 166-184.

Robinson, A., \& Tormey, S. (2009). Is 'another world' possible? Laclau, Mouffe and Social Movements. In A. Little \& M. Lloyd (Eds.), The politics of radical democracy. Edinburg: Edinburg University Press.

Shields, S. (2007). Too much shock, not enough therapy: Transnational capital and the social implications of Poland's ongoing transition to a market. Competition and Change, 11(2), 155-178.

Shields, S. (2015). Neoliberalism Redux: Poland's recombinant populism and its alternatives. Critical Sociology, 41(4-5), 659-678.

Stenning, A., Smith, A., Rochovska, A., \& Swiatek, D. (2010). Domesticating neoliberalism: Spaces of economic practice and social reproduction in post-socialist cities. Oxford: Wiley.

Tarrow, S. (1998). Power in movement: Social movements and contentious politics. New York \& Cambridge: Cambridge University Press. 
Thomassen, L. (2005). Antagonism, hegemony and ideology after heterogeneity. Journal of Political Ideologies, 10(3), 289-309.

Urbański, J. (2010). Polityka wysiedleń po polsku [Eviction Politics in Polish]. Le monde diplomatique, 11/57. Retrieved June 17, 2014 from http://monde-diplomatique.pl/LMD57/index.php?id= 1 3

Woś, R. (2014). Dziecięca choroba liberalizmu [Liberalism: An Infantile Disorder]. Warszawa: Wydawnictwo Studio Emka.

\section{Other sources}

Erbel, J. 2012-03-05, Krytyka Polityczna. Retrieved December 8, 2016 from http://www.krytykapolityczna.pl/Serwissamor zadowy/ErbelWarszawajestlatwopalna/menuid-403.html.

Facebook 2016-05-01. Retrieved December 8, 2016 from https:// www.facebook.com/events/1560292397618544/.

Jola Brzeska Wordpress (no date). Retrieved December 8, 2016 from https://jolabrzeska.files.wordpress.com/2013/03/jola-eng.pdf.

Kotomski, R. 2012-09-17. Niezalezna. Retrieved December 8, 2016 from http://niezalezna.pl/32967-wkladka-miesna-czyli-loka torzy-wedlug-hgw.
Lokatorzy.pl (no date). Retrieved December 8, 2016 from http:// www.lokatorzy.pl/kampania/o-co-chodzi-w-naszej-kampanii.

Lokatorzy.info.pl 2016-09-26. Retrieved December 8, 2016 from http://lokatorzy.info.pl/stop-wysiedlaniu-prazan/.

Lokatorzy.info.pl 2016-06-22. Retrieved December 8, 2016 from http://lokatorzy.info.pl/cykl-protestow-lokatorskich-pod-urze dami-dzielnic/.

Nosal-Ikonowicz, A. 2016-09-09. Krytyka Polityczna. Retrieved December 8, 2016 from http://www.krytykapolityczna.pl/arty kuly/opinie/20160909/adam-bodnar-rzecznik-zwyklych-ludzi.

Polsat 2016-10-18. Retrieved December 8, 2016 from http://www. polsatnews.pl/wiadomosc/2016-10-08/ikonowicz-to-kraj-wktorym-biedni-sa-na-cenzurowanym/.

Smosarski, A. (2007). Jak sie skutecznie organizować. Retrieved December 8, 2016 from http://www.lokatorzy.pl/pliki/pdf/SMO SARSKI_jak_sie_organizowac.pdf.

Zubik, M., \& Machajski, P. 2011-03-09. Gazeta Wyborcza. Retrieved December 8, 2016 from http://warszawa.wyborcza.pl/warszawa/ 1,34889,9222882,Lokatorzy_protestuja__Wszystkich_nas_nie_ spalicie_.html?disableRedirects=true. 